\title{
Matches and mismatches: ocean climate, prey phenology and breeding success in a zooplanktivorous seabird
}

\author{
J. Mark Hipfner* \\ Centre for Wildlife Ecology, Simon Fraser University and the Canadian Wildlife Service, RR\#1 5421 Robertson Road, Delta, \\ British Columbia V4K 3N2, Canada
}

\begin{abstract}
In the marine environment, climatic changes are asymmetrically altering the phenologies of species at different trophic levels, causing an increase in the severity of mismatching between predators and their prey. At Triangle Island (British Columbia, Canada), the zooplanktivorous seabird Cassin's auklet Ptychoramphus aleuticus breeds less successfully in warm-water years than in coldwater years. Previous researchers hypothesized that this occurred because, in warm years, there is less temporal overlap between the auklets' nestling-provisioning period and the period when the copepod Neocalanus cristatus, an important prey item, is available to the birds in near-surface waters. I tested this hypothesis with data collected between 1996 and 2006. As predicted by the match-mismatch hypothesis, the copepods became scarce in nestling diets 2 to 3 wk earlier in warmer than in colder years, and were less prevalent overall in warm years. The auklets' offspring were more likely to survive from hatching to fledging, and were heavier in mass at fledging, in years in which their diets were richer in $N$. cristatus. Information-theoretic approaches indicated that this effect of diet, a direct consequence of spring ocean temperature, outweighed other indirect influences of ocean temperature on offspring performance. Comparison with independent data on the timing and magnitude of local annual zooplankton biomass peaks indicated that prey timing, rather than prey abundance, was the key factor determining seasonal prevalence of the copepod in nestling diets. This study adds to a growing body of evidence showing that climate-driven phenological mismatches can alter critical trophic interactions, with potentially deleterious demographic consequences for predators.
\end{abstract}

KEY WORDS: Match-mismatch · Ocean climate $\cdot$ Auklet $\cdot$ Copepod

\section{INTRODUCTION}

A critical issue in ecology, especially in an age of rapidly changing climate, concerns how environmental variability influences ecosystem processes. In recent years, the match-mismatch hypothesis has been invoked frequently as a mechanism linking climatic variation to trophic perturbations across a range of ecosystem types (Visser et al. 1998, Anderson \& Piatt 1999, Platt et al. 2003, Drever \& Clark 2007). The central tenet of the match-mismatch hypothesis is that predators breed more successfully in years in which the most energetically demanding phase of their breeding cycle overlaps extensively (i.e. 'matches') with the seasonal peak in prey availability. In the marine environment, where the match-mismatch hypothesis has its roots (Cushing 1990), climatic changes are asymmetrically altering the phenologies of species at different trophic levels, causing an increase in the frequency and severity of mismatching between predators and their prey (Edwards \& Richardson 2004). Because many mid- to high-trophic-level marine predators, including many species of seabirds, rely heavily on one or a few prey species while breeding 
(Reid et al. 2006), strong temporal matching between their breeding period and the annual peak in the availability of key prey species can be vital to successful population processes (Regehr \& Montevecchi 1997, Durant et al. 2003, Suryan et al. 2006).

At Triangle Island (British Columbia, Canada), previous research showed that in cold, phenologically late years, when compared with warm, phenologically early years, offspring of the seabird Cassin's auklet Ptychoramphus aleuticus grew more quickly on diets that remained richer in the copepod Neocalanus cristatus until later in the season (Bertram et al. 2001, Hedd et al. 2002). Invoking the match-mismatch hypothesis, these authors proposed that the relationship was causal: in cold, late years, the period of maximal biomass of late-stage copepodites in surface waters begins late and ends late, matching well with the birds' energetically demanding chick-provisioning period (which is comparatively fixed), while in warm years, the peak occurs too early and spans too narrow a window of time for the birds. However, these baseline studies spanned just $4 \mathrm{yr}$, including only a single cold year, while a rigorous test of their hypothesis requires data spanning a range of ocean climatic conditions.

Characteristics of both the seabird predator and the copepod prey make this an excellent study system in which to investigate the match-mismatch hypothesis. Triangle Island supports the world's largest colony of the nocturnal and mainly zooplanktivorous Cassin's auklet (up to 0.5 million breeding pairs; Rodway 1990). Mismatching could have particularly severe consequences for an aggregation of this size because the intensity of intraspecific competition for food can increase with colony size in seabirds (Gaston et al. 1983, Forero et al. 2002). In addition, diets fed to offspring by auklet parents are strongly influenced by oceanographically driven variation in prey availability (Adams et al. 2004, Abraham \& Sydeman 2006, Springer et al. 2007). Moreover, Cassin's auklets at more northerly colonies commence breeding very early in the spring (Hatch \& Hatch 1990). Because the timing of avian breeding is largely entrained by an invariant photoperiod (Dawson 2008), auklets at northern sites might have limited capacity to further advance their timing of laying to match advances in their prey's phenology.

The timing of the zooplankton biomass peak in surface waters of the northeast Pacific is influenced very strongly by ocean climate (Mackas et al. 1998). Annual peaks occurred early during the 'warm-and-low-productivity' periods from 1992-1998 and 2003-2006, but later during the 'cool-and-high-productivity' period from 1999-2002 (Mackas et al. 2007, D. Mackas \& S. Batten pers. comm.). An important component of the region's mesozooplankton community, Neocalanus cristatus is a large, lipid-rich, subarctic copepod. In late winter, overwintering pre-adults mature, mate, and spawn at great depth; after hatching, early juveniles undergo a vertical ontogenetic migration to feed and grow in near-surface waters in the spring (Miller et al. 1984). As a result, the developing year class becomes available to Cassin's auklets for a brief but annually variable period (by several weeks) before returning to mesopelagic depths (1000 to $2000 \mathrm{~m}$ ) for a prolonged period of dormancy (Mackas \& Tsuda 1999). While provisioning nestlings, the auklets forage intensively for late-stage (C5) copepodites in surface waters along the continental shelf break 25 to $40 \mathrm{~km}$ west of Triangle Island (Boyd et al. 2008). Being relatively small $(\sim 170 \mathrm{~g})$ wing-propelled divers, Cassin's auklets can dive only to depths of $\sim 50 \mathrm{~m}$ to obtain prey (Burger \& Powell 1990).

Here, I use data collected over the environmentally variable $11 \mathrm{yr}$ period from 1996 to 2006 to test Bertram et al.'s (2001) match-mismatch model for this system. Their model makes several testable predictions $(\mathrm{P}$; Table 1): (P1) the copepod Neocalanus cristatus will remain an important component of Cassin's auklet

Table 1. Ptychoramphus aleuticus. Predictions of the match-mismatch hypothesis for provisioning nestlings with the copepod Neocalanus cristatus in 11 years (1996-2006) differing in ocean temperature at Triangle Island

\begin{tabular}{|c|c|c|}
\hline Related parameters & Prediction no. & Prediction \\
\hline \multirow[t]{2}{*}{$\begin{array}{l}\text { Ocean temperature and percentage } \\
\text { biomass of } N \text {. cristatus in nestling diets }\end{array}$} & $\mathrm{P} 1$ & $\begin{array}{l}N . \text { cristatus will persist longer in diets in cold ocean years } \\
\text { compared to warm ocean years. }\end{array}$ \\
\hline & $\mathrm{P} 2$ & $\begin{array}{l}\text { Because } N \text {. cristatus persists longer in diets in colder years, } \\
\text { it will also be more prevalent overall in diets in colder years. }\end{array}$ \\
\hline \multirow[t]{2}{*}{$\begin{array}{l}\text { Percentage biomass of } N \text {. cristatus in } \\
\text { nestling diets and offspring performance }\end{array}$} & P3 and P5 & $\begin{array}{l}\text { Fledging masses (P3) and the proportion surviving from } \\
\text { hatching to fledging (P5) will be higher in years in which } N \text {. } \\
\text { cristatus is more persistent and prevalent in diets. }\end{array}$ \\
\hline & $\mathrm{P} 4$ and $\mathrm{P} 6$ & $\begin{array}{l}\text { The seasonal decline in fledging masses (P4) and proportion } \\
\text { surviving from hatching to fledging (P6) will be less marked } \\
\text { in years in which } N \text {. cristatus persists longer in diets. }\end{array}$ \\
\hline
\end{tabular}


nestling diets until later in the season in cold ocean years compared to warm ocean years. This is expected because the seasonal cycle of Neocalanus spp. is prolonged and delayed in cold conditions (Mackas et al. 1998, Tadokoro et al. 2005, Mackas et al. 2007), creating greater temporal overlap between the auklets' chick-provisioning period and the period during which this prey item is available to them in near-surface waters. Because N. cristatus persists longer in diets in colder years, then (P2) it will also be more prevalent overall in diets in colder years.

This variation in diet is predicted to have 2 effects on Cassin's auklet offspring. First, (P3) they will have greater mass at fledging in years in which Neocalanus cristatus is more persistent and prevalent in their diets. This is expected because the copepod is a high-quality prey item, being conspicuous, lipid-rich and spatially predictable for foraging parents. In addition, (P4) the seasonal decline in fledging masses will be less marked in years in which $N$. cristatus persists longer in diets, because even late-hatched nestlings will receive this prey item in considerable quantities. I also consider variation in the proportion of offspring that survive the period between hatching and fledging, predicting that as with fledging masses, (P5) there will be a positive relationship between the overall representation of $N$. cristatus in nestling diets and the proportion that survive; and finally, that (P6) the seasonal decline in the proportion that survive will be less pronounced in years in which $N$. cristatus persists longer in diets.

\section{MATERIALS AND METHODS}

Study area. The study was conducted at Triangle Island, British Columbia, Canada (50 52' N, $129^{\circ} 05^{\prime} \mathrm{W}$ ), in each year from 1996 to 2006.

Field methods. About 80 nest sites (the birds use earthen burrows) were examined at $5 \mathrm{~d}$ intervals to monitor the timing and success of Cassin's auklet breeding in each year. Nest checks began in late March or early April, just prior to the start of laying, in all years except 2000 and 2001, when they began in mid-April, at the mid-laying stage. When an egg was first found, the burrow was left undisturbed for $35 \mathrm{~d}$, then again inspected at $5 \mathrm{~d}$ intervals until a hatchling was found. When first found, hatchling wing length ( $\pm 1 \mathrm{~mm}$, using a wing bar) and mass $( \pm 1 \mathrm{~g}$, using a $50 \mathrm{~g}$ spring scale) were measured. Hatching dates, thus nestling ages, were estimated using a calibration of wing length against age for known-aged nestlings based on measurements made previously at Triangle Island (Hedd et al. 2002). Nestlings were then measured and weighed at Ages 5, 10, 25 and $35 \mathrm{~d}$, and then every $2 \mathrm{~d}$ until they disappeared. They were consid- ered to have fledged successfully if they survived at least $35 \mathrm{~d}$ and were not later found dead in the burrow. Fledging mass was taken to be the last mass recorded prior to the chick's disappearance (nestling Cassin's auklets leave the burrow to begin an independent life at sea at an average age of 40 to $45 \mathrm{~d}$ ).

Approximately 10 provisioning adults were captured for diet sampling while returning to the colony in darkness using pheasant nets erected between 2 large poles. Sampling occurred at $10 \mathrm{~d}$ intervals beginning on 18 May (28 May in the very late 2005 season), and ending on 27 June ( 5 sessions in total per year, except 2005 when there were 4). This 6 wk interval corresponds well with the provisioning period of pairs that laid by the median laying date in most years. Occasionally, sampling sessions needed to be delayed by 1 to $3 \mathrm{~d}$ due to inclement weather, or they spanned 2 or 3 consecutive nights until $\sim 10$ samples were obtained. Adult auklets carry zooplankton to their young in a sublingual pouch. Upon capture, we massaged the adults' pouches to induce them to regurgitate their food loads through a funnel into a small, preweighed, screw-top plastic bottle, later filled with buffered formalin.

Laboratory methods. Regurgitated samples were transferred to stacked sieves and rinsed repeatedly with water to remove preservative. Individual items present in subsamples were identified to the lowest possible taxonomic level (usually species, especially for common items), enumerated, blotted dry, and weighed on an electronic balance. As in other recent studies of Cassin's auklet diet from the northeast Pacific (Abraham \& Sydeman 2004, Adams et al. 2004), prey species were identified and enumerated by $\mathrm{M}$. Galbraith, Institute of Ocean Sciences, Sidney, British Columbia. In statistical analyses, each individual food load was treated as an independent and equal sample, regardless of its mass or completeness. In all analyses, I used measures based on wet biomass of prey items in food loads.

Statistical approach. First, I examined factors that affected the percentage biomass of auklet nestling diets comprised of Neocalanus cristatus. As predictor variables, I used Year (1-11), Sampling session within the year (a surrogate for date; $1-5$ ), and their Interaction. The match-mismatch hypothesis predicts that the representation of $N$. cristatus in diets will vary among years, being more prevalent in colder years (P2); and that there will be a Year $\times$ Sampling session interaction, with the prey item more persistent in colder years (P1).

Second, I examined factors that affected post-hatching offspring survival and fledging masses. In these analyses, I considered only offspring that hatched by 25 May (73\% of the entire sample) because diets 
through most of the developmental periods of these earlier offspring were well covered by the sampling scheme. As predictor variables, I used Year, Hatching date, and their interaction. Again, the match-mismatch hypothesis predicts that both the proportion that survive to fledge and fledging masses will vary among years, with higher survival rates and heavier fledging masses in years with more Neocalanus cristatus (P3 and P5), and that there will be a Year $\times$ Hatching date interaction, with survival probability and fledging masses declining more steeply with increasing hatching date in years in which $N$. cristatus is less persistent in diets (P4 and P6).

Because they received support in the initial tests, I further tested P3 and P5 to assess how annual survival and mean fledging mass varied with both the annual mean proportion of Neocalanus cristatus in diets and the monthly mean sea surface temperature (measured at Pine Island, $100 \mathrm{~km}$ to the east of Triangle Island) as a proxy for local ocean primary productivity (Beamish et al. 1999). These latter analyses were run separately for each month between March and June because monthly temperatures were intercorrelated within years. Initially, I included the annual median hatching date and the proportion of euphausiids and ichthyoplankton in diets in models to predict survival and fledging mass, to assess whether the timing of breeding or choice of secondary prey species might play roles. However, there was no indication that they did. Therefore, I excluded these variables, which are not

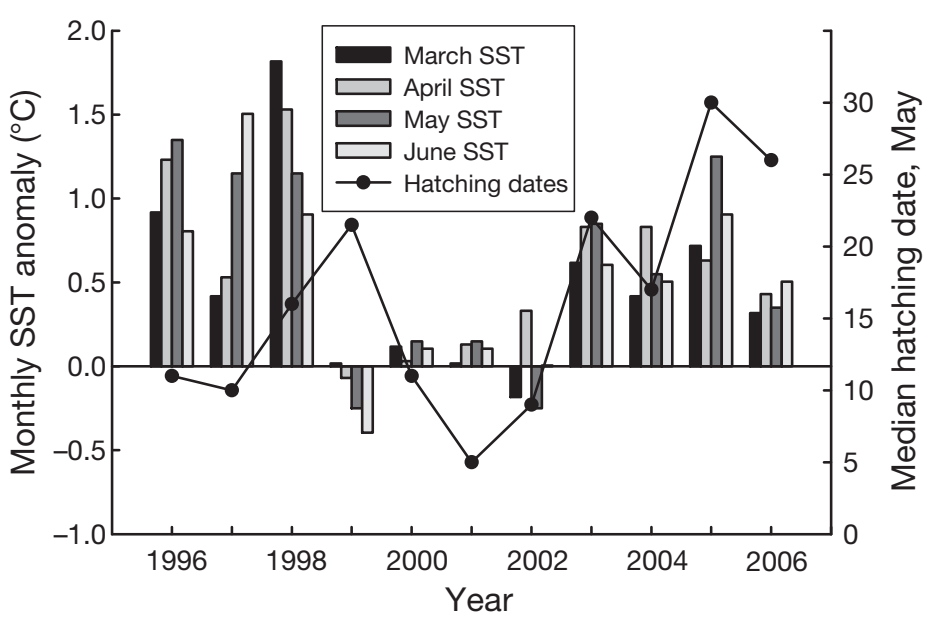

Fig. 1. Monthly sea surface temperature (SST) anomalies at Pine Island light station (100 km east of Triangle Island), 1996-2006, compared to long-term (1937-1995) averages (left axis, bars). The 3 temporal periods identified by Mackas et al. (2007) are evident: a 'warm-and-low-productivity' period until 1998, then a 'cool-and-high-productivity' period from 1999-2002, followed by another 'warm-and-lowproductivity' period from 2003-2005. Median hatching dates are superimposed (right axis, connected points) central to the Bertram et al. hypothesis, in order to minimize the number and complexity of the candidate model set (Burnham \& Anderson 2002).

All models within each candidate set of models were ranked using Akaike's Information Criterion corrected for small sample size $\left(\mathrm{AIC}_{\mathrm{C}}\right)$, based on the difference between each model's $\mathrm{AIC}_{\mathrm{c}}$ and the lowest $\mathrm{AIC}_{\mathrm{c}}$ from among the candidate set. In addition to selecting a single most-parsimonious model $\left(\Delta \mathrm{AIC}_{\mathrm{c}}=0.0\right)$, any models with $\Delta \mathrm{AIC}_{\mathrm{c}}$ scores $\leq 2$ can be considered to have received meaningful support (Burnham \& Anderson 2002). For analysis, percentage data were arcsinetransformed and I included quadratic terms in models to account for curvilinear relationships, e.g. fledging mass or survival versus sea surface temperature and auklet diets. Statistical analyses were performed with JMP v. 7 (SAS Institute 2007).

\section{RESULTS}

\section{Interannual variation}

Ocean climate

Compared to the long-term (1937-1995) average, sea surface temperatures at Pine Island were very warm from 1996 through 1998, near average from 1999-2002, then warm from 2003-2006 (Fig. 1). Thus, the 3 oceanographic periods identified by Mackas et al. (2007) were evident. For Cassin's auklets, population-wide annual median hatching dates were not systematically related to spring sea surface temperatures (for the month of March, $\mathrm{r}^{2}=0.05$; Fig. 1).

\section{Cassin's auklet nestling diets}

Across the 11 yr study period, Cassin's auklet nestling diets were dominated by 3 prey types: copepods (almost exclusively Neocalanus cristatus; annual mean $\sim 40 \%$ of biomass), euphausiids (4 species in highly variable proportions: Euphausia pacifica, Thysanoessa spinifera, T. inspinata, and small amounts of T. gregaria in 2004 to 2006 only; mean $\sim 40 \%$ of biomass), and ichthyoplankton (mean $\sim 15 \%$ of biomass; Fig. 2 ). Only 3 other prey types (the amphipod Vibilia propinqua, crab larvae, and the caridean Pandalus mysis) comprised $\geq 2.0 \%$ of the total biomass delivered to auklet nestlings in any year. For the 239 food loads judged to be complete at the time they were collected, year (1998 to 2006 only) and percentage biomass of $N$. cristatus combined in a generalized linear model (GLM) predicted very little $(6 \%)$ of the variation in load mass. 


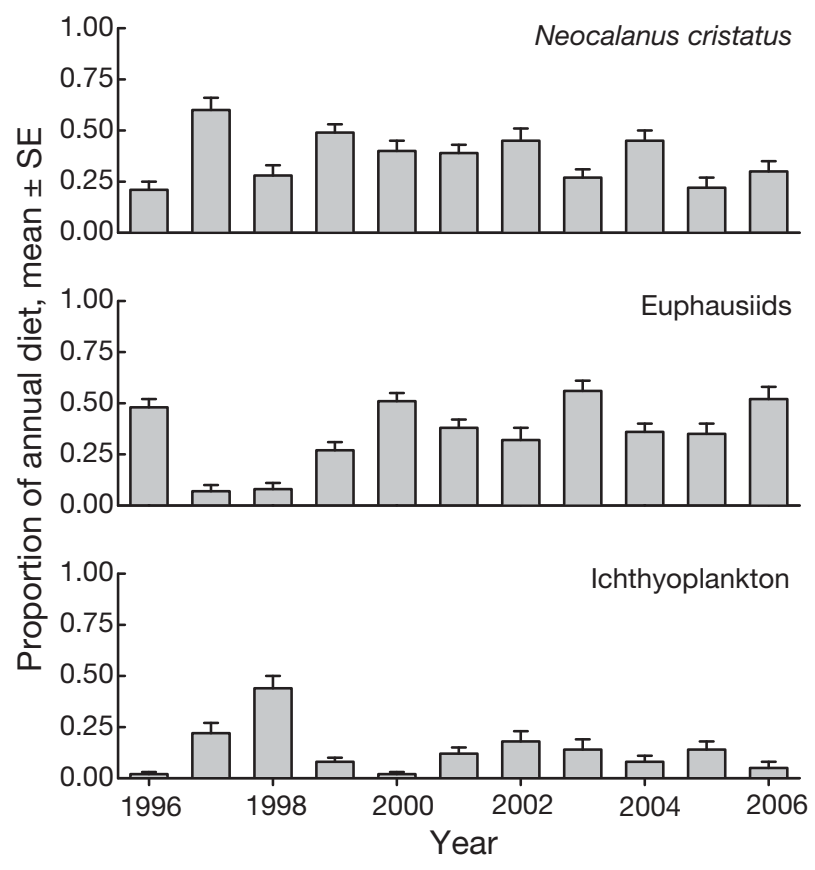

Fig. 2. Ptychoramphus aleuticus. Interannual variation in the proportion of mean $( \pm 1 \mathrm{SE})$ biomass across all individual food loads for the 3 major prey types in nestling diets at Triangle Island between mid-May and end of June 1996-2006. Euphausiids include 4 species (see 'Results')

\section{Tests of the match-mismatch model}

\section{Variation in Neocalanus cristatus in Cassin's auklet nestling diets (P1 and P2)}

In the analysis based on all 515 individual food loads, the global model including Year, Sampling session, and the Year $\times$ Session interaction term was best supported and had good predictive power $\left(\mathrm{R}^{2}=0.42\right)$. No other model received meaningful support (Table 2). Thus, the percentage biomass of the copepod Neocalanus cristatus in individual food loads delivered to nestling Cassin's auklets varied among years and declined with date within years. However, the withinseason patterns differed among years.

In accordance with predictions of the match-mismatch hypothesis, the copepod was similarly abundant early in the season in all years ( $50 \%$ of biomass on average on Sampling sessions 1 to 3 , from the middle of May until early June). However, it became scarce in nestling diets during the second half of June (Sessions 4 and 5) in the warm oceanic periods from 1996-1998 and 2003-2006, while remaining important through at least late June during the cold oceanic period from 1999-2002 (Fig. 3). Because it was less persistent, Neocalanus cristatus made up a smaller propor-
Table 2. Ptychoramphus aleuticus. Results of corrected Akaike's Information Criterion $\left(\mathrm{AIC}_{\mathrm{c}}\right)$ model comparisons to explain variation in the percentage biomass of Neocalanus cristatus in 515 nestling food loads collected in 5 sampling sessions in each of $11 \mathrm{yr}$ at Triangle Island. The bestsupported model was the global model, including Year, Sampling session and their interaction. No other model received meaningful support (all $\Delta \mathrm{AIC}>2.0$ ). $\mathrm{AIC}_{\mathrm{w}}=\mathrm{AIC}$ weight; $k=$ no. of parameters in the model

\begin{tabular}{|lcrrr}
\hline Model & $\mathrm{R}^{2}$ & $\Delta \mathrm{AIC}_{\mathrm{c}}$ & $\mathrm{AIC}_{\mathrm{w}}$ & $k$ \\
\hline Year + Session + Year $\times$ Session & 0.42 & 0.00 & 1.00 & 57 \\
Year + Session & 0.20 & 76.22 & 0.00 & 18 \\
Session & 0.11 & 119.99 & 0.00 & 7 \\
Year & 0.10 & 122.47 & 0.00 & 13 \\
Null & - & 164.38 & 0.00 & 2 \\
\hline
\end{tabular}

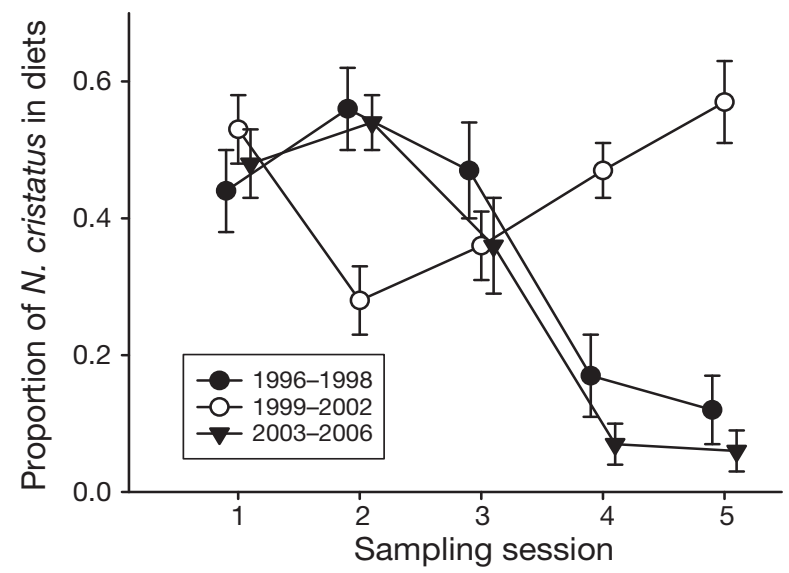

Fig. 3. Ptychoramphus aleuticus. Intra-annual variation in the proportion of mean biomass ( $\pm 1 \mathrm{SE}$ ) of Neocalanus cristatus in nestling diets from mid-May until end of June. Sampling sessions in each year are separated by $\sim 10 \mathrm{~d}$. Data were pooled across each sampling session and year within each of the 3 oceanographic periods identified by Mackas et al. (2007): the warm periods from 1996-1998 and 2003-2006, and the cold period from 1999-2002

tion of nestling diets in years in which the mean April (following Bertram et al. 2001) sea surface temperature was higher $\left(\Delta \mathrm{AIC}_{\mathrm{C}}=0.00\right.$ and $\mathrm{AIC}_{\mathrm{w}}=0.54$, compared to $\Delta \mathrm{AIC}_{\mathrm{C}}=0.20$ and $\mathrm{AIC}_{\mathrm{w}}=0.46$ for a null model; the linear regression equation is $\% N$. cristatus $=1.49-$ $0.13 \times$ April sea surface temperature; $r^{2}=0.28$ )

\section{Variation in Cassin's auklet fledging masses (P3 and P4) and survival (P5 and P6)}

In the GLM to explain variation in Cassin's auklet fledging masses ( $\mathrm{n}=353$ ), the model including year and hatching date was best supported, and had good predictive power $\left(\mathrm{R}^{2}=0.51\right)$. No other model received 
meaningful support (Table 3). Thus, fledging masses varied among years, and tended to decline with hatching date. However, the lack of interaction between year and hatching date indicates that the rate of decline differed little among years. The latter result is not consistent with predictions of the match-mismatch hypothesis.

The annual mean fledging mass was greater in years in which monthly mean sea surface temperatures were lower, and in years in which diets included more Neocalanus cristatus (Fig. 4). As predicted by the match-

Table 3. Ptychoramphus aleuticus. Results of $\mathrm{AIC}_{\mathrm{c}}$ model comparisons to explain variation in the fledging masses of 353 chicks over $11 \mathrm{yr}$ at Triangle Island. Note that the best-supported model included year and hatching date, but contrary to prediction, not their interaction. No other model received support (all $\Delta \mathrm{AIC}_{\mathrm{C}}>2.0$ )

\begin{tabular}{|lcrrrr|}
\hline Model & $\mathrm{R}^{2}$ & $\Delta \mathrm{AIC}_{\mathrm{c}}$ & $\mathrm{AIC}_{\mathrm{w}}$ & $k$ \\
\hline Year + Hatch date & 0.49 & 0.00 & 0.80 & 14 \\
Year & 0.48 & 2.72 & 0.20 & 13 \\
Year + Hatch date + Year $\times$ & 0.51 & 14.09 & 0.02 & 25 \\
$\quad$ Hatch date & & & & \\
Hatch date & 0.00 & 203.01 & 0.00 & 3 \\
Null & - & 1006.06 & 0.00 & 2 \\
\hline
\end{tabular}

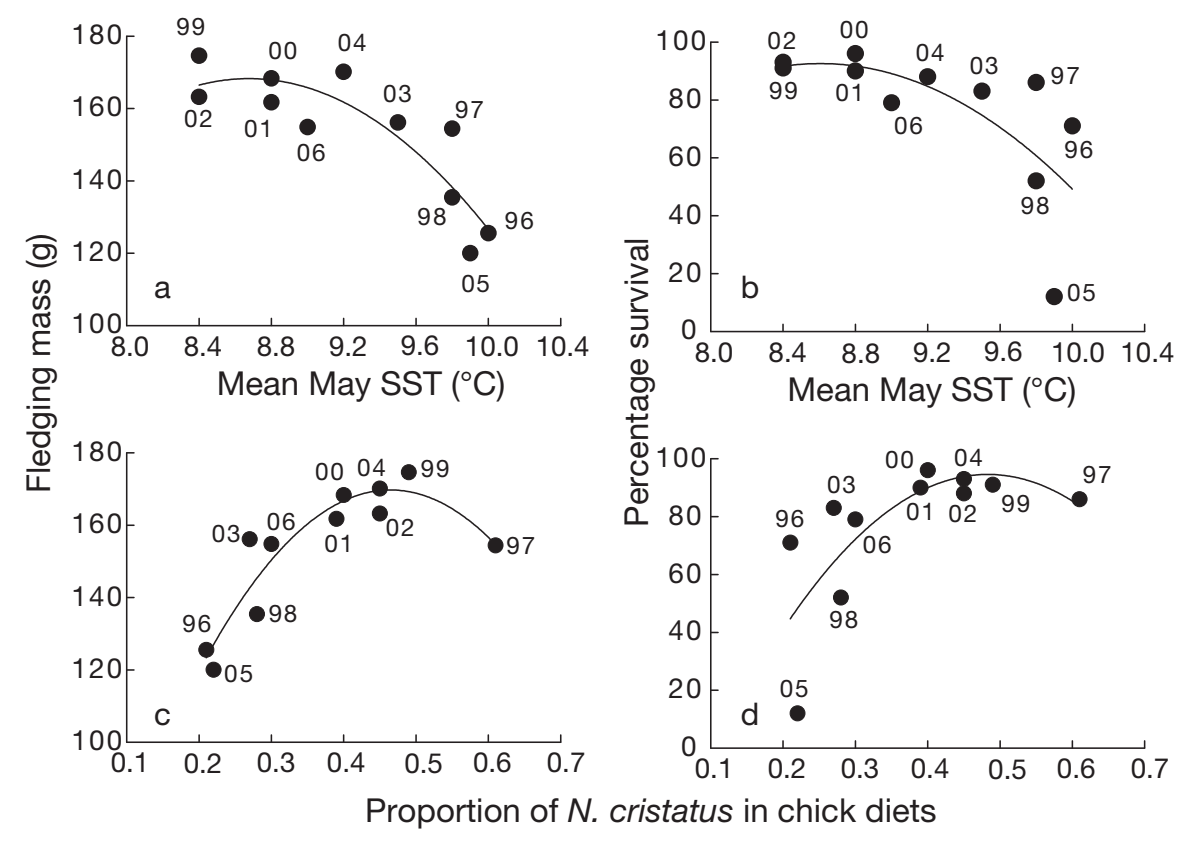

Fig. 4. Ptychoramphus aleuticus. $(\mathrm{a}, \mathrm{c})$ Annual mean fledging mass against the mean May sea surface temperature (SST) recorded at Pine Island $(a, b)$, and the mean annual proportion of Neocalanus cristatus biomass in nestling diets (c,d). (b,d) Annual proportion of nestlings that survive from hatching to fledging against the mean May SST recorded at Pine Island $(a, b)$, and the mean annual proportion of $N$. cristatus biomass in diets $(\mathrm{c}, \mathrm{d})$. Numbers near data points indicate the year (1996-2006) mismatch hypothesis, the most parsimonious model for explaining interannual variation in Cassin's auklet fledging mass was simply the proportion of $N$. cristatus in diets, regardless of the month (Table 4).

In the logistic analysis to explain variation in Cassin's auklet nestling survival ( $\mathrm{n}=413$ ), the model including year and hatching date was best supported, and had good predictive power $\left(\mathrm{R}^{2}=0.35\right)$. The model including the Year $\times$ Hatching date interaction also received support $\left(\Delta \mathrm{AIC}_{\mathrm{C}}<2.0\right)$, although it received less than half the weight of the best-supported model (Table 5). Thus, offspring survival varied among years, and tended to decline with later hatching but with only a weak tendency for the rate of seasonal decline in survival to vary among years.

Annual offspring survival was higher in years in which the monthly mean sea surface temperature was lower, and in years in which the annual mean percentage biomass of Neocalanus cristatus in individual food loads was higher (Fig. 4). For all months from March to June, the annual mean mass of $N$. cristatus in diets alone was the best-supported model to explain variation in survival. The null model was the only other model that received meaningful support $\left(\Delta \mathrm{AIC}_{\mathrm{C}}<2.0\right)$, but only in March. Thus, as with fledging mass, the most parsimonious model to account for interannual variation in Cassin's auklet nestling survival was simply the proportion of $N$. cristatus in diets.

\section{DISCUSSION}

Results of this study strongly support several of the more important predictions of the match-mismatch model developed for this predatorprey system (Bertram et al. 2001). The timing of Cassin's auklet hatching was not related systematically to ocean climate. As a result, the biomass of Neocalanus cristatus in auklet nestling diets varied among years, with this copepod being both more persistent (P1, by at least 2 to $3 \mathrm{wk}$ ) and more prevalent (P2) in diets in years in which spring sea surface temperatures were lower. While there is little information on temperature-phenology relationships specific to $N$. cristatus, life-cycle timing is later in colder years in other Neocalanus spp. whose life cycles are broadly similar (Mackas et al. 2007). In addition, Cassin's auklet chicks were more likely to survive to 
Table 4. Ptychoramphus aleuticus. Results of $\mathrm{AIC}_{\mathrm{c}}$ model comparisons to explain interannual variation in the mean fledging masses of a total of 353 chicks in $11 \mathrm{yr}$ at Triangle Island. To account for curvilinearity, I included both first and second order (variables marked ${ }^{2}$ ) terms for the predictor variables mean sea surface temperatures (SST) and proportion of Neocalanus cristatus in diets

\begin{tabular}{|c|c|c|c|c|c|}
\hline Month & Model & $\mathrm{R}^{2}$ & $\Delta \mathrm{AIC}_{\mathrm{c}}$ & $\mathrm{AIC}_{\mathrm{w}}$ & $k$ \\
\hline March & $\begin{array}{l}\% N . \text { cristatus + } \% \text { N. cristatus } \\
\text { Mean SST + Mean } \mathrm{SST}^{2}+\% \text { N. cristatus }+\% \text { N. cristatus } \\
\text { Mean SST + Mean } \mathrm{SST}^{2} \\
\text { Null }\end{array}$ & $\begin{array}{l}0.87 \\
0.92 \\
0.57 \\
-\end{array}$ & $\begin{array}{r}0.00 \\
8.33 \\
14.30 \\
15.93\end{array}$ & $\begin{array}{l}0.98 \\
0.02 \\
0.00 \\
0.00\end{array}$ & $\begin{array}{l}4 \\
6 \\
4 \\
2\end{array}$ \\
\hline April & $\begin{array}{l}\% N . \text { cristatus + } \% \text { N. cristatus } \\
\text { Mean SST }+ \text { Mean } \mathrm{SST}^{2}+\% \text { N. cristatus }+\% \text { N. cristatus } \\
\text { Null } \\
\text { Mean SST }+ \text { Mean } \mathrm{SST}^{2}\end{array}$ & $\begin{array}{c}0.87 \\
0.89 \\
- \\
0.45\end{array}$ & $\begin{array}{r}0.00 \\
13.43 \\
15.93 \\
17.18\end{array}$ & $\begin{array}{l}1.00 \\
0.00 \\
0.00 \\
0.00\end{array}$ & $\begin{array}{l}4 \\
6 \\
2 \\
4\end{array}$ \\
\hline May & $\begin{array}{l}\% \text { N. cristatus + } \% \text { N. cristatus } \\
\text { Mean SST + Mean } \text { SST }^{2} \\
\text { Mean SST + Mean } \text { SST }^{2}+\% \text { N. cristatus }+\% \text { N. cristatus } \\
\text { Null }\end{array}$ & $\begin{array}{l}0.87 \\
0.77 \\
0.92 \\
-\end{array}$ & $\begin{array}{r}0.00 \\
6.41 \\
8.47 \\
15.93\end{array}$ & $\begin{array}{l}0.95 \\
0.04 \\
0.01 \\
0.00\end{array}$ & $\begin{array}{l}4 \\
4 \\
6 \\
2\end{array}$ \\
\hline June & $\begin{array}{l}\% N . \text { cristatus + } \% \text { N. cristatus } \\
\text { Mean SST }+ \text { Mean } \mathrm{SST}^{2}+\% \text { N. cristatus }+\% \text { N. cristatus } \\
\text { Null } \\
\text { Mean SST + Mean } \mathrm{SST}^{2}\end{array}$ & $\begin{array}{c}0.87 \\
0.89 \\
- \\
0.49\end{array}$ & $\begin{array}{r}0.00 \\
12.50 \\
15.93 \\
16.22\end{array}$ & $\begin{array}{l}1.00 \\
0.00 \\
0.00 \\
0.00\end{array}$ & $\begin{array}{l}4 \\
6 \\
2 \\
4\end{array}$ \\
\hline
\end{tabular}

fledge (P5), and they fledged at heavier masses (P3), in years in which $N$. cristatus made up a greater proportion of their diets. The direct effect of diet on offspring survival and growth, itself a direct consequence of spring ocean climate, outweighed any indirect influence of sea surface temperature.

Only 2 of the model's predictions were not strongly supported. Fledging masses did not decline more steeply with later hatching in warmer than in colder years (P4), and there was only a weak tendency for survival to do so (P6). Experiments on several seabird species (Hatchwell 1991, De Forest \& Gaston 1996, Daunt et al. 1999), including Cassin's auklets (Morbey \& Ydenberg 2000, Hipfner et al. 2004), indicate that differences in the parental capacities of early and late breeders, rather than seasonal deteriorations in feeding conditions, often drive the ubiquitous seasonal declines in offspring performance. Thus, while the result is not consistent with predictions of the match-mismatch hypothesis, it is difficult to draw firm conclusions about the putative role of feeding conditions without experimenting to control for confounding factors.

The warm-spring versus cold-spring dichotomy in the persistence of Neocalanus cristatus in auklet nestling diets is consistent with direct studies of how ocean climate influences life-cycle timing in Neocalanus copepods in the northeastern Pacific (Mackas et al. 1998). Along the British Columbia continental margin near Triangle Island, Neocalanus copepod biomass in surface waters peaked during early to midApril in the warm periods from 1996-1998 and 2003-2005, but in late April to early May in 1999-2002 (Mackas et al. 2007). Based on these dates, biomass
Table 5. Ptychoramphus aleuticus. Results of $\mathrm{AIC}_{\mathrm{c}}$ model comparisons to explain variation in the post-hatching survival to fledging of 413 chicks over $11 \mathrm{yr}$ at Triangle Island. The best-supported model included year and hatching date, but not their interaction; however, the model including the interaction term also received meaningful support

\begin{tabular}{|lcccc|}
\hline Model & $\mathrm{R}^{2}$ & $\Delta \mathrm{AIC}_{\mathrm{c}}$ & $\mathrm{AIC}_{\mathrm{w}}$ & $k$ \\
\hline Year + Hatch date & 0.29 & 0.00 & 0.69 & 14 \\
Year + Hatch date + Year $\times$ & 0.35 & 1.60 & 0.31 & 25 \\
$\quad$ Hatch date & & & & \\
Year & 0.23 & 17.64 & 0.00 & 13 \\
Hatch date & 0.09 & 44.16 & 0.00 & 3 \\
Null & - & 74.40 & 0.00 & 2 \\
\hline
\end{tabular}

peaks in marine waters around Triangle Island generally fell during the auklets' egg production and early incubation periods in the warmer periods, but during late incubation and early in hatching in the colder period (Triangle Island Research Station unpubl. data). If we assume that birds attempt to time breeding so that they provision offspring during the seasonal peak in prey availability (Lack 1968), then the auklets better timed their breeding through the cold period. That tendency was associated with greater persistence and prevalence of $N$. cristatus in diets, and thus increased offspring performance.

If important prey was more readily available early, why did Cassin's auklets lay late in warmer springs, thus exacerbating the mismatching? Seabirds, like other birds, are thought to strategically time their breeding in response to early season environmental 
cues that predict feeding conditions later in the season (Frederiksen et al. 2004). However, energetics studies indicate that avian laying dates can be constrained by unfavourable feeding conditions (Stevenson \& Bryant 2000). In seabirds, for example, carryover effects from late winter and spring feeding conditions can affect the timing of laying (Daunt et al. 2006, Durant et al. 2006, Guinet et al. 2006). It is possible then that relatively poor feeding conditions in warm, unproductive years cause the auklets to lay too late (Ainley et al. 1990).

In terrestrial birds, individuals expend more energy while foraging to provision nestlings when temporally mismatched with their prey base (Thomas et al. 2001). Functionally, then, the increased energetic demand on provisioning adults, combined with offspring receiving less of the lipid-rich copepods, could largely explain the reduced breeding success of Cassin's auklets in mismatch years. Prey species might also be less lipidrich in warmer, less productive years as they themselves experience poor feeding conditions, with consequences for their predators (Wanless et al. 2005). While most auklet nestlings are fed at least once on most nights (Hedd et al. 2002), they might fare better when Neocalanus cristatus dominates diets because while this species is available, both parents are able to provision daily due to its spatial predictability. Notably, there was no suggestion that food loads containing $N$. cristatus were simply heavier than loads comprised of other species.

While temporal matching with the copepods' life cycle appeared to be critical for successful breeding by Cassin's auklets in this system, recent empirical and theoretical assessments of the match-mismatch hypothesis also consider how variation in prey abundance influences seasonal trophic interactions (Gotceitas et al. 1996, Durant et al. 2007). In particular, greater prey abundance could potentially override temporal mismatches between predator and prey. Even in a classic match-mismatch study system, modelling suggested that prey abundance can be more important than temporal matching for the Atlantic puffin Fratercula arctica feeding on herring Clupea harengus in Norway (Durant et al. 2005).

Mackas et al. (2001) found a positive association between the magnitude of the annual Neocalanus copepod biomass peak and the intensity of summer upwelling off southern British Columbia. Thus, we can expect these copepods to be more abundant in surface waters in years of colder ocean temperatures and stronger primary production. That tendency is evident when comparing the 1996-1998 period (which was warm and unproductive, with negative copepod biomass anomalies) against the 1999-2002 period (cold and productive, with positive copepod biomass anom- alies). However, through the warm 2003-2005 period, biomass anomalies were similar in magnitude and direction to those in the cold 1999-2002 period (Mackas et al. 2007); yet $N$. cristatus became scarce in Cassin's auklet diets early (in mid-June) as it had in 1996-1998. This difference suggests that the timing, rather than the magnitude, of the biomass peak is the more important determinant of the persistence of these copepods in auklet diets at Triangle Island. The fact that the prey item was similarly abundant $(\sim 50 \%$ of total biomass) in diets from mid-May until early June during both the cold and the 2 warm periods further supports this idea. In this auklet-copepod system compared to the puffin-herring system (Durant et al. 2005), both predator and prey tend to be closer trophically to primary production. While available in near-surface waters, the copepods may be superabundant relative to the birds' harvest in any year.

To summarize, Cassin's auklets at Triangle Island bred less successfully, with reduced offspring survival rates and fledging masses, in years with warmer ocean temperatures. As hypothesized previously (Bertram et al. 2001), results of the present study indicate that strong temporal mismatching with one specific prey species, the copepod Neocalanus cristatus, largely drove the poor breeding success in warm years. This study adds to a growing body of evidence showing that climate-driven phenological mismatches can dramatically alter trophic interactions, and that these disruptions have the potential to affect demographic processes in the predator (Both et al. 2006). This could be especially true in marine systems, in which temporal mismatching between trophic levels is both frequent and widespread (Anderson \& Piatt 1999, Edwards \& Richardson 2004). As the oceans continue to warm (IPCC 2007), we can expect the associated changes in the functioning of marine ecosystems to have considerable consequences.

Acknowledgements. Thanks to the many field workers who helped to collect data. Thanks also to D. Bertram for initiating the study, and to M. Court, J. Higham, C. Smith, R. Ydenberg and the Canadian Coast Guard for top-notch logistical support. M. Galbraith, Institute of Ocean Sciences, Sidney, deserves special thanks for enumerating prey items in the Cassin's auklet 'gurge' samples. The research was conducted under a Scientific Permit from the Canadian Wildlife Service and an Animal Care Permit from Simon Fraser University. Funding was provided by the Nestucca Oil Spill Trust Fund, the Climate Change Action Fund, the World Wildlife Fund Canada, the Science Horizons, Migratory Bird, and Birds Oiled at Sea programs of Environment Canada, the Natural Sciences and Engineering Research Council of Canada (grants to F. Cooke), and the Centre for Wildlife Ecology. Finally, I thank D. Esler and B. Smith for statistical advice, and D. Bertram, D. Mackas and B. Smith for constructive reviews of the draft manuscript. 


\section{LITERATURE CITED}

Abraham CL, Sydeman WJ (2004) Ocean climate, euphausiids and auklet nesting: inter-annual trends and variation in phenology, diet and growth of a planktivorous seabird, Ptychoramphus aleuticus. Mar Ecol Prog Ser 274:235-250

> Abraham CL, Sydeman WJ (2006) Prey-switching by Cassin's auklet Ptychoramphus aleuticus reveals seasonal climaterelated cycles of Euphausia pacifica and Thysanoessa spinifera. Mar Ecol Prog Ser 313:271-283

Adams J, Takekawa JY, Carter HR (2004) Stable foraging areas and variable chick diet in Cassin's auklets (Ptychoramphus aleuticus) off southern California. Can J Zool 82:1578-1595

Ainley DG, Boekelheide RJ, Morrell SH, Strong CS (1990) Cassin's auklet. In: Ainley DG, Boeklheide RJ (eds) Seabirds of the Farallon Islands: ecology, dynamics and structure of an upwelling-system community. Stanford University Press, Stanford, CA, p 306-338

Anderson PJ, Piatt JF (1999) Community reorganization in the Gulf of Alaska following ocean climate regime shift. Mar Ecol Prog Ser 189:117-123

Beamish RJ, Noakes DJ, McFarlane GA, Klyashtorin L, Ivanov VV, Kurashov V (1999) The regime concept and natural trends in the production of Pacific salmon. Can J Fish Aquat Sci 56:516-526

Bertram DF, Mackas DL, McKinnell SM (2001) The seasonal cycle revisited: interannual variation and ecosystem consequences. Prog Oceanogr 49:283-307

Both C, Bouwhuis S, Lessells CM, Visser ME (2006) Climate change and population declines in a long-distance migratory bird. Nature 441:81-83

Boyd WS, McFarlane-Tranquilla LA, Ryder JL, Shisko S, Bertram DF (in press) (2008) Interannual variation in diurnal marine distributions of Cassin's auklets (Ptychoramphus aleuticus) breeding at Triangle Island, British Columbia. Auk 125:158-166

Burger AE, Powell DW (1990) Diving depths and diet of Cassin's auklet at Reef Island, British Columbia. Can J Zool 68:1572-1577

Burnham KP, Anderson DR (2002) Model selection and multimodel inference. A practical information-theoretic approach. Springer, New York

Cushing DH (1990) Plankton production and year-class strength in fish populations - an update of the matchmismatch hypothesis. Adv Mar Biol 26:249-293

> Daunt F, Wanless S, Harris MP, Monaghan P (1999) Experimental evidence that age-specific reproductive success is independent of environmental effects. Proc R Soc Lond B Biol Sci 266:1489-1493

Daunt F, Afanasayev V, Silk JRD, Wanless S (2006) Extrinsic and intrinsic determinants of winter foraging and breeding phenology in a temperate seabird. Behav Ecol Sociobiol 59:381-388

> Dawson A (2008) Control of the annual cycle in birds: endocrine constraints and plasticity in response to ecological variability. Phil Trans R Soc Lond B Biol Sci 363: 1621-1633

De Forest LN, Gaston AJ (1996) The effect of age on timing of breeding and reproductive success in the thick-billed murre. Ecology 77:1501-1511

> Drever MC, Clark RG (2007) Spring temperature, clutch initiation date and duck nest success: a test of the mismatch hypothesis. J Anim Ecol 76:139-148

Durant JM, Anker-Nilssen T, Stenseth NC (2003) Trophic interactions under climate fluctuations: the Atlantic puffin as an example. Proc R Soc Lond B Biol Sci 270:1461-1466
Durant JM, Hjermann DØ, Anker-Nilssen T, Beaugrand G, Mysterud A, Pettorelli N, Stenseth NC (2005) Timing and abundance as key mechanisms affecting trophic interactions in variable environments. Ecol Lett 8:952-958

> Durant JM, Anker-Nilssen T, Stenseth NC (2006) Ocean climate prior to breeding affects the duration of the nestling period in the Atlantic puffin. Biol Lett 2:628-631

Durant JM, Hjermann DØ, Ottersen G, Stenseth NC (2007) Climate and the match or mismatch between predator requirements and resource availability. Clim Res 33: 271-283

Edwards M, Richardson AJ (2004) Impact of climate change on marine pelagic phenology and trophic mismatch. Nature 430:881-884

Forero MG, Tella JL, Hobson KA, Bertellotti M, Blanco G (2002) Conspecific food competition explains variability in colony size: a test in Magellanic penguins. Ecology 83: 3466-3475

Frederiksen M, Harris MP, Daunt F, Rothery P, Wanless S (2004) Scale-dependent climate signals drive breeding phenology of three seabird species. Glob Change Biol 10: 1214-1221

Gaston AJ, Chapdelaine G, Noble DG (1983) The growth of thick-billed murre chicks at colonies in Hudson Strait: inter- and intra-colony variation. Can J Zool 61:2465-2475

Gotceitas V, Puvanendran V, Leader LL, Brown JA (1996) An experimental investigation of the 'match-mismatch' hypothesis using larval Atlantic cod. Environ Biol Fishes 130:29-37

Guinet C, Chastel O, Koudil M, Durbec JP, Jouventin P (1998) Effects of warm sea surface anomalies on the blue petrel at the Kerguelen Islands. Proc R Soc Lond B Biol Sci 265: 1001-1006

Hatch SA, Hatch MA (1990) Breeding seasons of oceanic birds in a subarctic colony. Can J Zool 68:1664-1679

- Hatchwell BJ (1991) An experimental study of the effects of timing of breeding on the reproductive success of the common guillemot. J Anim Ecol 60:721-736

> Hedd A, Ryder JL, Cowen LL, Bertram DF (2002) Inter-annual variation in the diet, provisioning and growth of Cassin's auklet at Triangle Island, British Columbia: responses to variation in ocean climate. Mar Ecol Prog Ser 229:221-232

> Hipfner JM, Charleton K, Davies WE (2004) Rates and consequences of relaying in Cassin's auklets and rhinoceros auklets breeding in a seasonal environment. J Avian Biol 35:224-236

IPCC (Intergovernmental Panel on Climate Change) (2007). Climate change 2007 - the physical science basis. IPCC Secretariat, Geneva

Lack D (1968) Ecological adaptations for breeding in birds. Clarendon Press, London

> Mackas DL, Tsuda A (1999) Mesozooplankton in the eastern and western subarctic Pacific: community structure, seasonal life histories, and interannual variability. Prog Oceanogr 43:335-363

Mackas DL, Goldblatt R, Lewis AG (1998) Interdecadal variation in developmental timing of Neocalanus plumchrus populations at OSP in the subarctic North Pacific. Can J Fish Aquat Sci 55:1878-1893

Mackas DL, Thomson RE, Galbraith M (2001) Changes in the zooplankton community of the British Columbia continental margin, 1985-1999, and their covariation with oceanographic conditions. Can J Fish Aquat Sci 58:685-702

> Mackas DL, Batten S, Trudel M (2007) Effects on zooplankton of a warmer ocean: recent evidence from the Northeast Pacific. Prog Oceanogr 75:223-252

Miller CB, Frost BW, Batchelder HP, Clemons MJ, Conway RE 
(1984) Life histories of large, grazing copepods in a subarctic ocean gyre: Neocalanus plumchrus, Neocalanus cristatus, and Eucalanus bungii in the Northeast Pacific. Prog Oceanogr 13:201-243

Morbey Y, Ydenberg RC (2000) Seasonal decline in nestling growth: support for the parental quality hypothesis in Cassin's auklets. Auk 117:1065-1068

Platt T, Fuentes-Yaco C, Frank KT (2003) Spring algal bloom and larval fish survival. Nature 423:398-399

Regehr HM, Montevecchi WA (1997) Interactive effects of food shortage and predation on breeding failure of blacklegged kittiwakes: indirect effects of fisheries activities and implications for indicator species. Mar Ecol Prog Ser 155:249-260

Reid K, Murphy EJ, Croxall JP, Trathan PN (2006) Population dynamics of Antarctic krill Euphausia superba at South Georgia: Sampling with predators provides new insight. In: Boyd I, Wanless S, Camphuysen CJ (eds) Top predators in marine ecosystems: their role in monitoring and management. Cambridge University Press, Cambridge, p 249-261

Rodway MS (1990) Status and conservation of breeding seabirds in British Columbia. In: Croxall JP (ed) Supplement to the status and conservation of the world's seabirds. International Council for Bird Preservation, Cambridge, p 43-102

Editorial responsibility: Rory Wilson,

Swansea, UK
Springer AM, Byrd GV, Iverson SJ (2007) Hot oceanography: planktivorous seabirds reveal ecosystem responses to warming of the Bering Sea. Mar Ecol Prog Ser 352:289-297

> Stevenson IR, Bryant DM (2000) Climate change and constraints on breeding. Nature 406:366-367

Suryan RM, Irons DB, Brown ED, Jodice PGR, Roby DD (2006) Site-specific effects on productivity of an upper trophiclevel marine predator: bottom-up, top-down, and mismatch effects on reproduction in a colonial seabird. Prog Oceanogr 68:303-328

> Tadokoro K, Chiba S, Ono T, Midorikawa T, Saino T (2005) Interannual variation in Neocalanus biomass in the Oyashio waters of the western North Pacific. Fish Oceanogr 14:210-222

Thomas DW, Blondel J, Perret P, Lambrechts MM, Speakman JR (2001) Energetic and fitness costs of mismatching resource supply and demand in seasonally breeding birds. Science 291:2598-2600

Visser ME, Van Noordwijk AJ, Tinbergen JM, Lessels CM (1998) Warmer springs lead to mistimed reproduction in great tits (Parus major). Proc R Soc Lond B Biol Sci 265: $1867-1870$

- Wanless S, Harris MP, Redman P, Speakman JR (2005) Low energy values of fish as a probable cause of a major seabird breeding failure in the North Sea. Mar Ecol Prog Ser 294:1-8

Submitted: February 11, 2008; Accepted: June 10, 2008 Proofs received from author(s): September 5, 2008 